\title{
Relevansi Konsep Pendidikan Sosial Anak Perspektif Abdullah Nasih Ulwan dengan Tujuan Pendidikan Nasional
}

\author{
Sitti Atiyatul Mahfudoh \\ IAI Al Khairat Pamekasan \\ siti.atiyah.m@gmail.com \\ Ulva Badi’ Rohmawati \\ IAI Sunan Giri Bojonegoro \\ ulvabadi@gmail.com.
}

\begin{abstract}
Abstrak
Living in society is a necessity. However, in line with the development of an increasingly modern era, accompanied by the development of technology and increasingly concerning moral decade, it is also a challenge for an educator to strive for students not only to be reasonable quality, but also social quality. Because living in society is a necessity, it is also a challenge for an educator to be able to prepare their students to be a good members of society. One of the goals of national education is to develop students' potential to be faithful, pious, noble, healthy, knowledgeable, competent, creative, independent and have ability to enter the community well. Therefore, Abdullah Nasih Ulwah gave the concept of social education for children which is written in the book Tarbiyah Al-Awlad Fi Al-Islam. In his book stated that social education is educating children from an early age by directing and instilling a noble soul personality, so that they are able to hold fast in good social ethics based on Islamic aqidah and deep sense of faith, maintain and prioritize the rights of others, practice governance and also maintaining and saving social life in society. Thus, the child is able to adjust to the social environment with good social ethics and good manners, mature thinking, and acting wisely. Abdullah Nasih Ulwah's Thinking is very relevant if it is related with the goals of national education.
\end{abstract}

\begin{abstract}
Abstrak
Hidup bermasyarakat adalah sebuah keniscayaan. Namun seiiring dengan berkembangnya zaman yang semakin modern, diiringi dengan semakin berkembangnya teknologi serta dekadensi moral yang semakin memprihatinkan, maka menjadi tantangan juga bagi seorang pendidik untuk mengupayakan agar peserta didik tidak hanya berkualitas secara akal, tapi berkualitas juga secara sosialnya. Karna hidup bermasyarakat merupakan keniscayaan, maka menjadi tantangan juga bagi seorang pendidik agar bisa mempersiapkan peserta didiknya menjadi anggota masyarakat yang baik. Salah satu dari tujuan Pendidikan nasional adalah mengembangkan potensi peserta didik menjadi manusia yang beriman, bertakwa, berakhlak mulia, sehat, berilmu, cakap, kreatif, mandiri, serta mempunyai kemampuan untuk terjun ke tengah masyarakat dengan baik. Oleh karena itu Abdullah Nasih ulwan memberikan konsep Pendidikan sosial bagi anak yang beliau tulis dalam kitab Tarbiyah Al-Awlad Fi Al-Islam. Menurutnya, Pendidikan sosial
\end{abstract}


yaitu mendidik anak sejak dini dengan mengarahkan dan menanamkan kepribadian jiwa yang luhur, sehingga mampu berpegang teguh dengan etikaetika sosial yang baik yang berlandaskan aqidah Islam dan perasaan iman yang dalam, Memelihara juga mengutamakan hak-hak orang lain, mengamalkan tata krama atau adab sosial, serta menjaga dan menyelamatkan kehidupan sosial bermasyarakat. Dengan demikian si anak mampu menyesuaikan diri dalam lingkungan sosial kemasyarakatan dengan etika pergaulan dan adab yang baik, pemikiran yang matang, dan bertindak secara bijaksana. Pemikiran Abdullah Nasih Ulwan ini sangat relevan jika dihubungkan dengan tujuan Pendidikan nasional.

Kata Kunci: Pendidikan, Sosial, Anak, Abdullah Nasih Ulwan, Tujuan Pendidikan nasional 


\section{Pendahuluan.}

Seiring dengan perkembangan zaman yang semakin modern, diiringi dengan semakin berkembangnya teknologi, maka menjadi tantangan juga bagi seorang pendidik untuk mengupayakan agar peserta didik tidak hanya berkualitas secara akal, tapi berkualitas juga secara sosialnya. Karna hidup bermasyarakat merupakan suatu keniscayaan, maka menjadi tantangan juga bagi seorang pendidik agar bisa mempersiapkan peserta didiknya menjadi anggota masyarakat yang baik dan setiap generasi perlu di upayakan supaya menjadi individu masyarakat yang terbaik dan mempunyai etika sosial yang baik . Oleh karena itu, peserta didik terutama anak-anak perlu di bimbing dan di arahkan untuk mengenal nilai-nilai sosial kemasyarakatan melalui tahapan atau fase tertentu sebelum kemudian hidup dalam masyarakat yang luas.

Melalui berbagai macam hasil pengamatan dan hasil dari fakta-fakta empiris telah dibuktikan bahwa kuatnya bangunan suatu masyarakat amat bergantung pada individu dari anggota masyarakat tersebut. Oleh karna itu di dalam Islam sangat ditekankan adanya pendidikan sosial anak sejak dini agar anak dapat berperilaku baik. Baik didalam perilaku pribadinya maupun didalam perilaku sosialnya dengan harapan apabila mereka telah diberikan pendidikan yang baik maka akan terbentuk sikap baik didalam perilakunya. Maka mereka akan sanggup untuk terjun dalam kehidupan bermasyarakat dengan citra dan perilaku yang baik sebagai seorang yang dikenal baik, disiplin, seimbang, serta bijaksana.

Berdasarkan uraian di atas maka pendidikan sosial kemasyarakatan sangat dibutuhkan. Pendidikan sosial masyarakatan merupakan pendidikan yang mempersiapkan anak-anak untuk tugasnya sebagai penghasil dan pemakai. ${ }^{1}$ Pendidikan memegang peranan penting dalam pembentukan sosial anak. Sehingga dengan pendidikan sosial, anggapan tentang tata cara, dan pola tingkah laku manusia hanya ditentukan oleh faktor fisik dan kultural dapat terbantahkan. ${ }^{2}$

Pertanyaan yang muncul selanjutnya adalah bagaimanakah cara mendidik sosial anak? Abdullah Nasih Ulwan menawarkan konsepnya. Menurutnya; Pendidikan sosial anak yaitu mendidik anak sejak dini dengan mengarahkan dan menanamkan kepribadian

\footnotetext{
${ }^{1}$ Solaeman Joesoef, Konsep Dasar Pendidikan Luar Sekolah, (Jakarta : Bumi Aksara, 2004), 91.

${ }^{2}$ Abu Ahmadi, Sosiologi Pendidikan, (Jakarta : Rineka Cipta, 1991), 43.
} 
jiwa yang luhur, sehingga mampu berpegang teguh dengan etika-etika sosial yang baik yang berlandaskan aqidah Islam dan perasaan iman yang dalam, Memelihara juga mengutamakan hak-hak orang lain, mengamalkan tata krama atau adab sosial, menjaga dan menyelamatkan kehidupan sosial bermasyarakat. Dengan demikian si anak mampu menyesuaikan diri dalam lingkungan sosial kemasyarakatan dengan etika pergaulan dan adab yang baik, pemikiran yang matang, dan bertindak secara bijaksana. ${ }^{3}$

Berdasarkan uraian di atas, maka pendidikan hendaklah berorientasi pada kemanusiaan. Kepribadian atau karakteristik terbentuk sebagai hasil pengasuhan dalam keluarga yang telah terbentuk dalam diri anak. Sedangkan persoalan yang mungkin ditimbulkan oleh keterbukaan yang bersumber dari teknologi informasi, adanya konflik antara keluarga, juga persoalan yang lainnya, sangat mungkin akan dibawa ke lembaga. Mengingat bahwasanya aspek dari tumbuh kembang anak usia dini sangat kompleks, baik perkembangan secara kognitif, fisik, maupun psikomotorik, maka sangat penting untuk pemerintah untuk turut serta dalam melakukan pembinaan dan pendidikan untuk mengembangkan berbagai aspek tersebut secara profesional melalui lembaga-lembaga terkait. $^{4}$

Manusia sebagai mahluk individu sekaligus mahluk sosial tentu mempunyai kebutuhan. Baik keutuhan yang bersifat individu ataupun kebutuhan sosial didalam kehidupannya. Kebutuhan tersebut meliputi berbagai aspek kehidupan. Baik dari aspek yang bersifat individu atau aspek sosial. Seperti kebutuhan dari segi politik, sosial, ekonomi, serta pendidikan. Yang terakhir disebut yaitu pendidikan, merupakan suatu kebutuhan yang sangat penting bahkan terpenting karena menyangkut terbentuknya generasi yang akan datang dalam rangka memenuhi kebutuhan tersebut. ${ }^{5}$

Melalui pendidikan, maka anak akan dibimbing, dibina, serta diarahkan secara sadar dan sengaja melalui sistem yang teroganisir. Melalui pendidikan sosial, anggapan tentang tata cara, dan pola tingkah laku manusia hanya ditentukan oleh faktor fisik dan kultural dapat terbantahkan. Sebab pendidikan memegang peranan penting dalam pembentukan sosial anak. ${ }^{6}$

\footnotetext{
${ }^{3}$ Abdullah Nasih Ulwan, Tarbiyatul Awlad fi al-Islam Juz 1, (Beirut : Darussalam, t.th), 306-307.

${ }^{4}$ Nusa Putra dan Ninin Dwi Lestari, Penelitian Kualitatif PAUD, ( Jakarta : Raja Grafindo Persada, 2012), 34.

${ }^{5}$ Zakiah Darajat, Ilmu Pendidikan Islam, (Jakarta: Bumi Aksara, 2000), 23.

${ }^{6}$ Abu Ahmadi, Sosiologi Pendidikan, (Jakarta : Rineka Cipta, 1991), 43.
} 
Abdullah Nasih Ulwan memberikan cara mendidik sosial anak yang dapat diterapkan dalam ranah teoritis dan praktis. Menurutnya; diantara cara mendidik anak dengan pendidikan sosial yang baik adalah mendidik anak sejak dini dengan etika sosial yang baik dan menanamkan kepribadian jiwa yang luhur, yang bersumber dari akidah islam dan perasaan iman yang dalam. Memelihara dan mengutamakan hak-hak orang lain, mengamalkan tata krama atau adab sosial, menjaga dan menyelamatkan kehidupan sosial bermasyarakat. Dengan demikian si anak dapat hidup dengan etika sosial yang baik. $^{7}$

\section{Pengertian dan Tujuan Pendidikan Sosial Anak}

Pendidikan dapat diartikan sebagai pembinaan, pengarahan, pembentukan, pencerdasan, dan pelatihan yang ditujukan kepada semua anak didik secara formal maupun non formal dengan tujuan membentuk anak didik yang cerdas, berkepribadian, memiliki keterampilan atau keahlian tertentu sebagai bekal kehidupannya dalam masyarakat. ${ }^{8}$ Pendidikan adalah suatu aktivitas untuk mengembangkan seluruh aspek kepribadian manusia yang berjalan seumur hidup. Pendidikan tidak hanya sebatas pengembangan intelektual melainkan mengembangkan seluruh aspek kepribadian manusia. Pendidikan merupakan sarana utama untuk mengembangkan kepribadian setiap manusia. ${ }^{9}$ Menurut Ki Hajar Dewantara pendidikan dapat diartikan sebagai usaha yang dilakukan dengan penuh keinsyafan yang ditujukan untuk keselamatan dan kebahagiaan manusia. Pendidikan adalah usaha kebudayaan, berasas peradaban, yakni memajukan hidup agar mempertinggi derajat kemanusiaan. ${ }^{10}$

Pendidikan yang lebih hakiki lagi adalah pembinaan akhlak manusia. Menurut Syekh Musthafa al-Ghalayaini, pendidikan adalah menanamkan akhlak. Sehingga pendidikan akhlak bisa tertanam kuat dalam jiwa. Sejatinya pendidikan itu adalah menanamkan akhlak yang utama, budi pekerti yang baik serta didikan yang mulia dalam jiwa anak sejak dini. Karena jiwa seorang anak bagaikan lilin yang dapat dengan mudah

\footnotetext{
${ }^{7}$ Abdullah Nasih Ulwan, Tarbiyatul Awlad fi al-Islam Juz 1, (Beirut : Darussalam, t.th), 306-307.

${ }^{8}$ Muhaimin, Paradigma Pendidikan Islam: Upaya Mengefektifkan Pendidikan Agama Islam di Sekolah, ( Bandung: Rosdakarya, 2001), 37.

${ }^{9}$ Zuhairini,dkk, Filsafat Pendidikan Islam, (Jakarta: Bumi Aksara, 2004), 149.

${ }^{10} \mathrm{Ki}$ Hajar Dewantara, Bagian Pertama Pendidikan, (Yogyakarta: Majelis Luhur Persatuan Taman Siswa, 1992), 166.
} 
diukir sesuai dengan yang diinginkan, atau bagaikan kamera yang mampu mencetak gambar yang diambil melalui lensanya. ${ }^{11}$

Sosial adalah berkenaan dengan masyarakat dan dapat diartikan pula sebagai pergaulan hidup. Yang dimaksud dengan pendidikan sosial disini adalah pendidikan tentang etika sosial sehingga bisa menjadi anggota masyarakat yang baik. ${ }^{12}$ Dalam kamus besar bahasa Indonesia Kata sosial diartikan suka memperhatikan kepentingan umum, seperti suka menolong, menderma dan sebagainya. ${ }^{13}$ Menurut Sahal Mahfudh, sosial berarti segala sesuatu yang berkaitan dengan masyarakat yang menyangkut berbagai fenomena dan persoalan hidup dan kehidupan orang banyak, baik dilihat dari sisi mikro individual dan makro. ${ }^{14}$

Secara psikologi anak berarti mahluk yang dikaruniai mental dan emosional. Yang harus disadari adalah anak belum mampu untuk mengatur ataupun mengendalikan emosi disebabkan perkembangan jiwanya belum sempurna. Karena anak masih sangat membutuhkan adanya perhatian, adanya bimbingan, serta kasih sayang orang tua. Hal ini akan menjadi penentu bagi perkembangan anak di masa yang akan datang. Anak merupakan mahluk yang mempunyai keingintahuan yang tinggi dalam segala hal. Anak sedang dalam proses dalam mempelajari segala perilaku sosial disekitarnya sebagai bekal bagi dirinya untuk menjalani kehidupan sosial sosial bermasyarakat yang lebih tinggi di masa yang akan datang. ${ }^{15}$

Kartini Kartono mengatakan bahwa anak secara psikologis akan menyesuaikan dengan lingkungan dan melakukan tugas tertentu. Ada banyak tugas yang harus dilatihnya agar mampu melakukan adaptasi sosial dan ampu mempertahankan keberlangsungan hidupnya. Secara sosiologis anak adalah mahluk sosial yang senantiasa berinteraksi dengan anggota masyarakat. Dia hidup bersama ayah dan ibunya dalam ruang lingkup sosial kecil, yaitu keluarga. Di luar keluarga anak juga berinteraksi dan bermasyarakat dengan anggota masyarakat yang lain. ${ }^{16}$

\footnotetext{
${ }^{11}$ Musthafa A-Ghalayaini, 'Izhah al-Nasyi'in, (Surabaya : al-Hidayah, t.t), 189.

12 Nurseno, Sosiologi, (Solo: Tiga Serangkai Mandiri, 2004), 2.

${ }^{13}$ Tim Penyusun Kamus Pusat Pembinaan dan Pengembangan Bahasa Departemen Pendidikan dan Kebudayaan, Kamus Besar Bahasa Indonesia (Jakarta: Balai Pustaka,1993), 53.

${ }^{14}$ M.A. Sahal Mahfudh, Nuansa Fiqih Sosial (Yogyakarta: Pustaka Pelajar, 1994), 257.

${ }^{15}$ Elizabeth Hurlock, Psikologi perkembangan Anak, (Jakarta: Erlangga, 1991), 108.

${ }^{16}$ Kartini Kartono, Psikologi Anak, (Bandung: Alumni, 1982), 84.
} 
Pendidikan sosial dapat diartikan bimbingan dan arahan atau usaha sadar, yang terencana, dan sistematis, yang akan terus berlangsung untuk mewujudkan tujuan agar peserta didik mampu mengembangkan potensinya agar dapat memiliki kepribadian, kecerdasan, pengendalian diri, adab dan tatakrama yang baik, dan juga keterampilan dalam dirinya yang sangat diutuhkan ketika dia hidup bermasyarakat nanti. ${ }^{17}$

Pendidikan anak yaitu pendidikan yang diselenggarakan dengan tujuan untuk memfasilitasi pertumbuhan dan perkembangan anak secara menyeluruh aspek kepribadian anak. Baik kognitif, bahasa, sosial, emosi, fisik, dan motorik. ${ }^{18}$

Adapun tujuan pendidikan sosial anak menurut tugas dan fungsi manusia adalah mempersiapkan dirinya dalam kehidupan bermasyarakat. Berdasarkan uraian terseut diatas, dapat disimpulkan bahwa tujuan dari pendidikan sosial yaitu mempersiapkan anak didik agar dapat menjadi manusia yang sempurna akal serta akhlakul karimahnya baik sebagai individu ataupun sebagai bagian dari masyarakat dalam kehidupan bermasyarakatnya. ${ }^{19}$

\section{Pendidikan Sosial Anak Perspektif Abdullah Nasih Ulwan}

Pendidikan sosial anak menurut Abdullah Nasih Ulwan yaitu mendidik anak sejak dini dengan mengarahkan dan menanamkan kepribadian jiwa yang luhur, sehingga mampu berpegang teguh dengan etika-etika sosial yang baik yang berlandaskan aqidah Islam dan perasaan iman yang dalam, Memelihara juga mengutamakan hak-hak orang lain, mengamalkan tata krama atau adab sosial, serta menjaga dan menyelamatkan kehidupan sosial bermasyarakat. Dengan demikian si anak mampu menyesuaikan diri dalam lingkungan sosial kemasyarakatan dengan etika pergaulan dan adab yang baik, pemikiran yang matang, dan bertindak secara bijaksana. ${ }^{20}$

Berdasarkan uraian di atas, maka pendidikan hendaklah berorientasi pada kemanusiaan sehingga dapat menghormati kepribadian yang telah terbentuk dalam diri anak. Kepribadian atau karakteristik terbentuk sebagai hasil pengasuhan dalam keluarga. ${ }^{21}$

\footnotetext{
${ }^{17}$ Yudrik Yahya, Wawasan Kependidikan, (Jakarta: Depdiknas, 2004), 2.

${ }^{18}$ Barbara A. Lewis, Character Building Untuk Anak-Anak, ( Batam: Karisma Publishing, 2004), 6.

${ }^{19}$ M. Arifin, Ilmu Pendidikan Islam Tinjauan Teoritis dan Praktis, (Jakarta: Bumi Aksara, 2003), 27.

${ }^{20}$ Abdullah Nasih Ulwan, Tarbiyatul Awlad fi al-Islam Juz 1, (Beirut : Darussalam, t.th), 306-307.

${ }^{21}$ Nusa Putra dan Ninin Dwi Lestari, Penelitian Kualitatif PAUD, ( Jakarta : Raja Grafindo Persada, 2012), 34.
} 
Menurut Abdullah Nasih Ulwan, pendidikan sosial anak berkisar pada empat hal pokok berikut ini. Yaitu; Menanamkan dasar-dasar jiwa yang luhur, yang bersumber dari akidah islam dan perasaan iman yang dalam. Memelihara dan mengutamakan hak-hak orang lain. Mengamalkan tata krama atau ada sosial. Menjaga dan menyelamatkan kehidupan sosial bermasyarakat. Kami akan menjelaskan Secara rinci materi apa saja tentang pendidikan sosial dalam pandangan Abdullah Nasih Ulwan seagai berikut;

1. Menanamkan kepriadian luhur di dalam jiwa

Inti utama dari pendidikan adalah menanamkan kepriadian yang luhur di dalam jiwa. Dalam upaya menanamkan kepriadian luhur di dalam jiwa individu maupun kelompok, Islam telah memberikan tuntunan bagaimana pendidikan sosial bisa berada di dalam kepriadian luhur serta tujuan baik yang diharapkan. Sehingga tiap individu bisa hidup bermasyarakat atas dasar ikatan yang kuat, saling tolong menolong dalam kebaikan, memiliki etika yang baik, saling cinta dan kasih, serta dapat bersama memberikan kritik yang dapat membangun demi kehidupan sosial bermasyarakat yang baik.

Adapun kepriadian luhur yang diarahkan di dalam Islam dalam pandangan Abdullah Nasih Ulwan yaitu : Takwa, Persaudaraan sesama muslim (Ukhuwwah), Kasih sayang, Mementingkan orang lain ( Itsar), Memaafkan, Berani karena benar (alJur'ah).

2. Memelihara dan Mengutamakan hak orang lain

Adapun memelihara dan mengutamakan hak orang lain yaitu mengupayakan agar anak didik terbiasa sejak usia dini untuk menjaga serta menghormati hak-hak orang lain. Hak- hak masyarakat merupakan suatu keniscayaaan. Dan perlu dimengerti bahwa memelihara dan mengutamakan hak-hak sosial orang lain adalah keharusan dan seyogyanya harus disertai dengan kepribadian luhur dan baik. ${ }^{22}$

Adapun maksud dari hak disini ialah semacam milik atau kepunyaan, dan tidak terbatas pada benda saja, tetapi juga pada hasil pemikiran. Lantas, hak-hak sosial apa saja yang penting untuk kita ajarkan kepada anak-anak kita, yang dapat dijadikan dasar landasan bagi mereka dalam hidup bermasyarakat yang harus kita tanamkan dan kita biasakan agar mereka terbiasa melakukan hal tersebut dengan baik, menurut Abdullah Nasih Ulwan hak-hak masyarakat yang paling penting dan harus menjadi perhatian

\footnotetext{
${ }^{22}$ Ibid., 290.
} 
bagi seorang anak, dimana kita harus membimbingnya agar mereka terbiasa menegakkannya dengan baik adalah Hak Orang Tua, Hak Saudara, Hak Tetangga, Hak Guru, Hak Teman, Hak orang yang lebih tua. ${ }^{23}$

3. Mengamalkan tata krama atau adab sosial

Mendidik anak sejak dini agar mengetahui dan memahami adab bermasyarakat yang baik dan membentuk akhlaknya adalah hal yang penting. Mengamalkan tata krama sosial sejak dini merupakan upaya yang harus dibiasakan dalam menjalankan adab sosial secara umum. Tujuannya, bila sudah dewasa dapat menangkap esensi dari segala sesuatu dan dapat bergaul di tengah masyarakat dengan kebaikan yang maksimal dan simpatik, serta budi perkerti yang luhur. ${ }^{24}$

Adapun adab sosial yang penting dan harus diajarkan kepada anak agar mereka terbiasa dengan perilaku tersebut menurut Abdullah Nasih Ulwan yaitu; adab makan dan minum, adab mengucapkan salam, adab minta izin, adab majlis atau duduk dalam pertemuan, adab berbicara, adab bercanda, adab memberi ucapan selamat, adab menjenguk orang sakit, adab melayat (ta'ziah), adab bersin dan menguap.

4. Menjaga dan menyelamatkan kehidupan sosial bermasyarakat

Diantara hal penting yang perlu ditanamkan pada anak sejak dini adalah kemampuan dan keberanian dalam Menjaga dan menyelamatkan kehidupan sosial bermasyarakat dengan berani mengingatkan dan menasehati orang-orang yang menyimpang. Membiasakan anak sejak dini untuk Menjaga dan menyelamatkan kehidupan sosial bermasyarakat adalah hal yang harus kita ajarkan dan biasakan sejak dini. Agar ketika dewasa dia terbiasa untuk menasehati dan memberikan perbaikan guna menyelamatkan kehidupan sosial masyarakat di sekitarnya. Oleh karna itu sangatlah dibutuhkan pendidik yang sadar dan mampu untuk mengajarkan dan menanamkan akhlak serta keberanian kepada anak didik agar mereka terbiasa berkata benar dimulai dari semenjak kecil, sehingga apaila sang anak telah berusia cukup untuk mampu memerikan kritik, nasehat, dan bicara tentang kebenaran, mereka akan mampu untuk dapat melaksanakan dan menjalankan kewajiban memeri nasehat dan ikut bertanggung jawab dalam menyelamatkan kehidupan sosial masyarakat dengan sebaik-baiknya. ${ }^{25}$

\footnotetext{
23 Ibid., 292.

${ }^{24}$ Ibid., 327.

${ }^{25}$ Ibid., 361.
} 
Ada beberapa cara dan tahapan untuk menanamkan dan membiasakan anak mampu Menjaga dan menyelamatkan kehidupan sosial masyarakat Sehingga para pendidik dapat mempersiapkan anak didik untuk bisa melakukan pengawasan dan penjagaan terhadap kehidupan sosial masyarakat. Diantara tahapan tersebut yaitu; Pertama, Memelihara dan menjaga kehidupan sosial masyarakat dengan nasehat atau petuah yang baik atau Amar makruf nahi mungkar Sudah merupakan kewajiban bagi umat islam untuk melaksanakan amar makruf nahi mungkar (memerintahkan kebaikan dan mencegah dari kemungkaran). Memelihara dan menjaga kehidupan sosial masyarakat dengan nasehat atau petuah yang baik dalam segala bentuk dan jenisnya adalah kewajiban agi setiap orang. Baik ulama, pemerintah, civitas akademika, praktisi, cendekia, laki-laki maupun perempuan, tua atau muda, anak-anak serta dewasa, pegawai beserta pekerja, serta masyarakat secara umum, tugas untuk memelihara dan menjaga kehidupan sosial bermasyarakat dibebankan kepada setiap individu tanpa terkecuali. ${ }^{26}$

Kedua, Aturan dalam Memelihara dan menjaga kehidupan sosial masyarakat. Memerintahkan berbuat baik dan mencegah perbuatan mungkar tetap harus memakai aturan yang telah ditentukan. Para pendidik dan orang tua harus mengajarkan kaidahkaidahnya agar anak dapat memahami dan menjalankannya dengan benar. Sehingga proses dalam Amar makrufnahi mungkar dalam rangka dakwah mendapat respon yang baik dan memiliki pengaruh yang kuat. Diantara kaidah dan syaratnya adalah; (a) Sebaiknya antara perkataan dengan perbuatan harus selaras; (b0 Perbuatan mungkar itu telah jelas kemungkarannya. (c) Bertahap dalam melarang kemungkaran; (d) Bersikap lemah lembut, dan berperilaku yang baik; $€$ Bersikap sabar atas kesulitan dan kesakitan

ketiga, Selalu mengingat hal yang dicontohkan oleh para pendahulu atau salafus sholeh. Tidak dapat dipungkiri bahwa mengingat dan mencontoh para pendahulu atau salafus sholeh adalah salah satu cara agar keberanian dapat timbul dalam diri seorang muslim dan dapat bersikap tegas untuk melaksanakan amar makruf nahi mungkar. Para salafus sholihin merubah kemungkaran dan meluruskan penyimpangan yang terjadi pada masa mereka dengan keteladanan yang baik. ${ }^{27}$

\footnotetext{
${ }^{26}$ Ibid., 327.

${ }^{27}$ Ibid., 376.
} 


\section{Relevansi pemikiran Abdullah Nasih Ulwan tentang pendidikan sosial anak dengan tujuan pendidikan nasional}

Pertama, Relevansi Teoritis. Pendidikan merupakan suatu sistem yang di dalamnya terdapat berbagai komponen yang saling berhubungan antara satu komponen dengan komponen lainnya. Apabila salah satu komponen tersebut tidak berfungsi dengan baik, maka akan mengakibatkan terganggunya proses pendidikan secara keseluruhan.

Pendidikan mempunyai peran yang sangat strategis dan sangat penting guna menumbuhkan potensi diri setiap peserta didik dalam rangka mewujudkan cita-cita bangsa Indonesia untuk meningkatkan kesejahteraan umum serta mencerdaskan kehidupan bangsa sebagaimana dirumuskan tentang tujuan pendidikan nasional pada Undang-undang Republik Indonesia No. 20 Tahun 2003 tentang Sistem Pendidikan Nasional yang menjelaskan bahwa pendidikan dilaksanakan untuk mencapai tujuan yang diharapkan bersama yaitu:

"Pendidikan adalah usaha sadar dan terencana untuk mewujudkan suasana belajar dan proses pembelajaran agar peserta didik secara aktif mengembangkan potensi dirinya untuk memiliki kekuatan spiritual keagamaan, pengendalian diri, kepribadian, kecerdasan, akhlak mulia, serta keterampilan yang diperlukan dirinya, masyarakat, bangsa dan negara" 28

Merujuk pada Undang-undang Sistem Pendidikan Nasional, dinyatakan bahwa pendidikan yaitu usaha sadar guna membentuk peserta didik melalui proses pengarahan, pembelajaran, dan latihan untuk berperan aktif sehingga berguna di masa yang akan datang. Oleh karenanya tujuan utama dari pendidikan yaitu mempersiapkan peserta didik sebagai generasi penerus dengan kecakapan pengetahuan, rasa tanggung jawab, keterampilan, dan kehalusan budi pekerti sehingga memiliki kemampuan untuk terjun ke tengah masyarakat dan lingkungannya.

Dalam Garis-Garis besar Haluan Negara (GBHN) yang merupakan ketetapan MPR NO. IV/ MPR/1978 juga mengatakan, bahwa tujuan pendidikan nasional adalah meningkatkan ketakwaan kepada Tuhan Yang Maha Esa, kecerdasan, keterampilan, mempertinggi budi pekerti, memperkuat kepribadian, mempertebal semangat

\footnotetext{
${ }^{28}$ Undang-undang Sistem Pendidikan Nasional (Jakarta: Sinar Grafika, 2007), 2.
} 
kebangsaan agar dapat menumbuhkan manusia-manusia pembangun yang dapat membangun dirinya sendiri serta bertanggung jawab atas pembangunan bangsa. ${ }^{29}$

Dengan demikian dapat kita fahami dengan sangat jelas bahwa pendidikan adalah aktivitas yang sengaja dilakukan dengan tujuan supaya peserta didik mempunyai kecakapan pengetahuan, kepribadian dan perilaku yang baik, sehingga wujud nyata dari penerapan pendidikan yang sesuai dengan Sistem Pendidikan Nasional (Sisdiknas) dan UU No. 20 Tahun 2003 dan GBHN TAP MPR NO.IV/ 1978 dapat terlaksana dengan baik.

Selanjutnya, objek dari pendidikan adalah siswa. Anak didik sebagai manusia muda yang masih dalam taraf potensial, manusia yang belum sampai pada taraf maksimal. Maka dari itu, pendidikan menjadi sangat penting dalam kehidupan manusia, sebab disamping sebagai makhluk biologis, manusia juga merupakan seorang pribadi, seorang person, dan seorang subyek. artinya, mereka mampu memahami kedudukannya, dapat menempatkan dirinya dalam setiap keadaannya, serta mampu mengambil sikap dalam menentukan arah dan tujuan hidup yang mereka cita-citakan. Agar anak didik dapat melakukan proses pendidikan dan pembelajaran, maka sangat diperlukan adanya bimbingan. Karena bimbingan merupakan bagian yang integral dari pendidikan, maka tujuannya berafiliasi kepada tujuan pendidikan secara utuh. ${ }^{30}$

Bimbingan sebagai bagian dari pendidikan memiliki tujuan khusus, yaitu membantu individu atau anak didik untuk mengembangkan dirinya secara optimal, sehingga ia dapat menemukan dirinya dan dapat mengadakan pilihan keputusan dan penyesuaian diri secara aktif dengan lingkungannya. Kebiasaan-kebiasaan haruslah dibentuk, kecakapan-kecakapan harus dipelajari dan dikembangkan sebelum ia dianggap sanggup atau dapat berdiri sendiri dan dapat menyesuaikan dirinya. Pendidikan merupakan suatu kegiatan yang sangat besar manfaatnya bagi kehidupan manusia sebagai individu maupun sebagai bagian dari keragaman masyarakat.

\footnotetext{
${ }^{29}$ Mohammad Ali, Pendidikan Untuk Pembangunan Nasional, (Bandung: Imperial Bhakti Utama, 2009), 15.

${ }^{30}$ Abu Ahmadi, Nur Uhbiyati, Ilmu Pendidikan (Jakarta: Rineka Cipta, 2003), 71.
} 
Pendidikan merupakan wujud manifestasi semangat menuntut ilmu pengetahuan untuk mencapai derajat yang tinggi dalam pandangan Allah SWT.

Dalam Kitab Tarbiyah al-Awlad fi al-Islam Abdullah Nasih Ulwan menjelaskan bahwa pendidikan sosial menurutnya hendaknya lebih mengarahkan akan pentingnya pembentukan akhlakul karimah peserta didik di dalam sosial kemasayarakatan berdasarkan prinsip ketakwaan. Pemikiran Pendidikan sosial Abdullah Nasih Ulwan di dalam kitabnya tersebut menekankan kepada para pendidik untuk memberikan arahan-arahan yang berharga membimbing agar pendidikan sosial berjalan di atas nilai yang luhur dan tujuan yang sempurna perlu ditanankan pendidikan ketakwaan, persaudaraan, menjaga hak orang lain, beradab dalam kehidupan sosial kemasyarakatan, adab berpendapat dan kritik sosial.

Berdasarkan undang-undang RI No. 20 tahun 2003 pasal 3 di dikatakan bahwa pendidikan nasional mempunyai fungsi mengembangkan kemampuan dan membentuk watak serta peradaban bangsa yang bermartabat dalam rangka mencerdaskan kehidupan bangsa, bertujuan untuk berkembangnya potensi peserta didik agar menjadi manusia yang beriman dan bertaqwa kepada Tuhan yang Maha Esa, berakhlak mulia, sehat, berilmu, cakap, kreatif, mandiri, dan menjadi warga negara yang demokratis dan bertanggung jawab. Kata "takwa" dalam kalimat di atas melahirkan penafsiran "mendidik manusia untuk menjadi insan yang baik, sehingga secara otomatis menjadi warga negara yang bermanfaat”.

Kedua, Relevansi Praktis. Seiring dengan berkemangnya zaman dan semakin canggihnya teknologi di masa sekarang dan kompleksitasnya kehidupan, maka sudah sepatutnya orang tua, pendidik juga masyarakat perlu untuk tetap memperhatikan dinamika kehidupan, utamanya dalam mengarahkan dan membimbing putra-putrinya, sehingga dapat meningkatkan potensi diri mereka dengan kehalusan budi pekerti yang tinggi dengan harapan dapat menjadi Pribadi yang bertakwa dan berakhlakul karimah. Oleh karena itu menjadi suatu kewajiban bagi orang tua maupun guru dalam mengarahkan dan mendidik mereka tentang moral dan etika yang baik, agar mereka mengerti dan mampu membedakan sesuatu yang baik maupun yang buruk, mana yang benar dan mana yang salah. Dalam hal ini yang perlu di perhatikan dan di terapkan oleh seorang pendidik yaitu memberikan porsi besar dalam keteladan baik mengenai 
sikap, perbuatan maupun perkataan. Karena anak didik lebih mudah meniru apa yang mereka saksikan daripada melaksakan pesan kata-kata.

Ironis sekali ketika Bangsa ini sedang ingin bangkit dari keterpurukan, dan hendak menata kembali keadaannya, tetapi masih saja marak perilaku-perilaku menyimpang. Fenomena terjadinya diseintregasi, penyalahgunaan iptek, pendangkalan iman, materialistik, menghalalkan segala cara, stres, frustasi, kehilangan harga diri dan masa depan. Di tengah tantangan krisis moral serta kerusakan social inilah. Konsep pendidikan sosial menurut Abdullah Nasih Ulwan dalam Kitab Tarbiyah al-Awlad fi al-Islam dapat menjadi rujukan yang realistis dan komprehensif. Apalagi jika dikaitkan dengan tujuan pendidikan nasional di Indonesia, pemikiran beliau tentang pendidikan sosial anak ini sangat relevan. Bagi para pendidik baik orang tua, guru, dan masyarakat jika mengharapkan anak-anaknya menjadi manusia yang mempunyai akhlak yang baik dalam kehidupan sosialnya, maka harus memberikan bekal yang cukup bagaimana tata cara beretika dan berperilaku baik di dalam kehidupan masyarakat. Pendidik hendaknya memberikan keteladanan dan membiasakan anak-anak untuk berprilaku baik sehingga dapat mereka terapkan dalam kehidupan mereka sehari-hari. Dengan demikian kehadiran mereka di tengah-tengah masyarakat akan membawa dampak yang baik, memberi banyak manfaat baik untuk masa kini maupun masa yang akan datang sehingga tercapailah kebahagiaan serta kesejahteraan yang diharapkan, baik di dunia maupun di akhirat.

\section{Kesimpulan}

Konsep pemikiran Abdullah Nasih Ulwan dalam kitab Tarbiyah al-Awlad Fi al-Islam mengenai pendidikan sosial anak yaitu mendidik anak sejak dini dengan mengarahkan dan menanamkan kepribadian jiwa yang luhur sehingga mampu berpegang teguh dengan etika-etika sosial yang baik yang berlandaskan aqidah Islam dan perasaan iman yang dalam, Memelihara dan mengutamakan hak-hak orang lain, mengamalkan tata krama atau adab sosial, serta menjaga dan menyelamatkan kehidupan sosial bermasyarakat. Hal ini sangat relevan jika dihubungkan dengan tujuan pendidikan nasional. Hal ini dibuktikan dengan mengacu pada tujuan dari pendidikan nasional di Indonesia. Sebagaimana yang tercantum dalam Undangundang Republik Indonesia No. 20 Tahun 2003 tentang Sistem Pendidikan Nasional 
yang menyatakan bahwa pendidikan dilakukan untuk mendapatkan tujuan yang diharapkan bersama yakni: "Pendidikan adalah usaha sadar dan terencana untuk mewujudkan suasana belajar dan proses pembelajaran agar peserta didik secara aktif mengembangkan potensi dirinya untuk memiliki kekuatan spiritual keagamaan, pengendalian diri, kepribadian, kecerdasan, akhlak mulia, serta keterampilan yang diperlukan dirinya, masyarakat, bangsa dan negara" .

Merujuk kepada Undang-Undang tentang pendidikan dan tujuan nasional dari pendidikan, maka dapat kami simpulkan bahwasanya pemikiran Abdullah Nasih Ulwan tentang pendidikan sosial anak sangat relevan jika dihubungkan dengan tujuan pendidikan di Indonesia. Pemikiran Abdullah Nasih Ulwan tentang konsep pendidikan sosial anak ini tidak hanya bersifat teoritis tapi juga bersifat praktis sehingga diharapkan anak dapat mengimplementasikan nilai-nilai tersebut dalam konteks kehidupan sehari-hari. 


\section{Referensi}

Ahmadi, Abu dan Nur Uhbiyati. 2003. Ilmu Pendidikan. Jakarta: Rineka Cipta.

Ahmadi, Abu. 1991. Sosiologi Pendidikan. Jakarta : Rineka Cipta.

Al-Ghalayaini, Musthafa. T.Th. 'Izhah Al-Nasyi'in. Surabaya : Al-Hidayah.

Ali, Mohammad. 2009. Pendidikan Untuk Pembangunan Nasional. Bandung: Imperial Bhakti Utama.

Arifin, M. 2003. Ilmu Pendidikan Islam Tinjauan Teoritis Dan Praktis. Jakarta: Bumi Aksara.

Darajat, Zakiah. 2000. Ilmu Pendidikan Islam. Jakarta: Bumi Aksara.

Darajat, Zakiah.1991. Ilmu Jiwa Agama. Jakarta: Bulan Bintang.

Dewantara, Ki Hajar. 1992. Bagian Pertama Pendidikan. Yogyakarta: Majelis Luhur Persatuan Taman Siswa.

Hurlock, Elizabeth. 1991. Psikologi Perkembangan Anak. Jakarta: Erlangga.

Joesoef, Solaeman. 2004. Konsep Dasar Pendidikan Luar Sekolah. Jakarta : Bumi Aksara.

Kartono, Kartini. 1982. Psikologi Anak. Bandung: Alumni.

Lewis, Barbara A. 2004. Character Building Untuk Anak-Anak. Batam: Karisma Publishing.

Mahfudh, Sahal. 1994. Nuansa Fiqih Sosial. Yogyakarta: Pustaka Pelajar.

Muhaimin,. 2001. Paradigma Pendidikan Islam: Upaya Mengefektifkan Pendidikan Agama Islam di Sekolah. Bandung: Rosdakarya.

Nurseno. 2004. Sosiologi. Solo: Tiga Serangkai Mandiri.

Putra, Nusa Dan Ninin Dwi Lestari. 2012. Penelitian Kualitatif PAUD. Jakarta : Raja Grafindo Persada.

Suyadi Dan Maulidya Ulfah. 2013. Konsep Dasar PAUD. Bandung: Remaja Rosda Karya.

Tim Penyusun Kamus Pusat Pembinaan Dan Pengembangan Bahasa Departemen Pendidikan Dan Kebudayaan. 1993. Kamus Besar Bahasa Indonesia. Jakarta: Balai Pustaka.

Ulwan, Abdullah Nashih. T.Th. Tarbiyah Al-Aulad Fi Al-Islam, Juz I. Beirut: Darussalam.

Undang-Undang Sistem Pendidikan Nasional (Jakarta: Sinar Grafika, 2007) 
FIKROTUNA; Jurnal Pendidikan dan Manajemen Islam Volume. 12, Nomor. 02, Desember 2020

Yahya, Yudrik. 2004. Wawasan Kependidikan. Jakarta: Depdiknas.

Zuhairini,dkk. 2004. Filsafat Pendidikan Islam.Jakarta: Bumi Aksara. 